Check for updates

Cite this: RSC Adv., 2018, 8, 1071

\title{
Enhanced heterogeneous Fenton-like degradation of methylene blue by reduced $\mathrm{CuFe}_{2} \mathrm{O}_{4} \dagger$
}

\author{
Qingdong Qin, ${ }^{a}$ Yahong Liu, ${ }^{a}$ Xuchun Li, ${ }^{b}$ Tian Sun ${ }^{a}$ and Yan Xu (D) *a
}

To facilitate rapid dye removal in oxidation processes, copper ferrite $\left(\mathrm{CuFe}_{2} \mathrm{O}_{4}\right)$ was isothermally reduced in $\mathrm{a} \mathrm{H}_{2}$ flow and used as a magnetically separable catalyst for activation of hydrogen peroxide $\left(\mathrm{H}_{2} \mathrm{O}_{2}\right)$. The physicochemical properties of the reduced $\mathrm{CuFe}_{2} \mathrm{O}_{4}$ were characterized with several techniques, including transmission electron microscopy, X-ray diffraction, X-ray photoelectron spectroscopy and magnetometry. In the catalytic experiments, reduced $\mathrm{CuFe}_{2} \mathrm{O}_{4}$ showed superior catalytic activity compared to raw $\mathrm{CuFe}_{2} \mathrm{O}_{4}$ for the removal of methylene blue (MB) due to its relatively high surface area and loading $\mathrm{Fe}^{O} / \mathrm{Cu}^{0}$ bimetallic particles. A limited amount of metal ions leached from the reduced $\mathrm{CuFe}_{2} \mathrm{O}_{4}$ and these leached ions could act as homogeneous Fenton catalysts in MB degradation. The effects of experimental parameters such as $\mathrm{pH}$, catalyst dosage and $\mathrm{H}_{2} \mathrm{O}_{2}$ concentration were investigated. Free radical inhibition experiments and electron spin resonance (ESR) spectroscopy revealed that the main reactive species was hydroxyl radical $\left({ }^{\circ} \mathrm{OH}\right)$. Moreover, reduced $\mathrm{CuFe}_{2} \mathrm{O}_{4}$ could be easily separated by using an external magnet after the reaction and remained good activity after being recycled five times, demonstrating its promising long-term application in the treatment of dye wastewater.

Received 16th November 2017 Accepted 21st December 2017

DOI: $10.1039 / c 7 r a 12488 k$

rsc.li/rsc-advances
Recently, heterogeneous Fenton-like processes have been investigated as a more practical and efficient alternative technique for removing recalcitrant organic pollutants. ${ }^{4}$ Many iron based catalysts, such as $\mathrm{Fe}_{2} \mathrm{O}_{3},{ }^{5} \mathrm{Fe}_{3} \mathrm{O}_{4},{ }^{6} \alpha-\mathrm{FeOOH}^{7}$ and $\mathrm{CuFe}_{2} \mathrm{O}_{4}{ }^{8,9}$ have been applied to activate $\mathrm{H}_{2} \mathrm{O}_{2}$ into reactive radicals for the degradation of organic pollutants in water. In particular, $\mathrm{CuFe}_{2} \mathrm{O}_{4}$, a kind of magnetic material with cubic structure, has received considerably higher attention in water treatment due to its high magnetic permeability, excellent chemical and mechanical stability. ${ }^{\mathbf{1 0}}$ Feng et al. prepared $\mathrm{CuFe}_{2} \mathrm{O}_{4}$ nanoparticles as a heterogeneous Fenton-like catalyst to degrade sulfanilamide and found that the pseudo-first-order rate constant was $5.9 \times 10^{-3} \mathrm{~min}^{-1}$. $^{8}$ Wang et al. synthesized mesoporous $\mathrm{CuFe}_{2} \mathrm{O}_{4}$ as a heterogeneous Fenton-like catalyst to degrade imidacloprid and reported that the apparent reaction rate constant was $1.7 \times 10^{-2} \mathrm{~min}^{-1} .{ }^{9}$ However, $\mathrm{CuFe}_{2} \mathrm{O}_{4}$ seems to present weak catalytic activity due to its low electron transfer rate, which limits the practical application of heterogeneous Fenton-like catalyst.

Zero-valent $\mathrm{Fe}\left(\mathrm{Fe}^{0}\right)$ has proved to be an efficient catalyst for the heterogeneous Fenton-like reaction due to the generation of ferrous iron by the corrosion of metal iron. ${ }^{\mathbf{1 1 , 1 2}}$ In addition, $\mathrm{Fe}^{0}$ as an electrons donor could reduce $\mathrm{Fe}^{3+}$ to $\mathrm{Fe}^{2+}$, which could be able to accelerate the formation of ${ }^{\circ} \mathrm{OH} .{ }^{13}$ Nevertheless, $\mathrm{Fe}^{0}$ trends to aggregate and forms large particles due to strong anisotropic dipolar interactions, which leads to a decrease in surface area and ultimately a lower catalytic activity. ${ }^{14}$ Therefore, it is essential to anchor and immobilize $\mathrm{Fe}^{0}$ onto supports to prevent aggregation. Several studies have supported $\mathrm{Fe}^{0}$ on
${ }^{a}$ School of Civil Engineering, Southeast University, Nanjing 210096, China. E-mail: xuxucalmm@seu.edu.cn; Fax: +86 25 83790757; Tel: +86 2583790757

${ }^{b}$ School of Environmental Science and Engineering, Zhejiang Gongshang University, Hangzhou 310018, China

$\dagger$ Electronic supplementary information (ESI) available. See DOI: $10.1039 / \mathrm{c} 7 \mathrm{ra} 12488 \mathrm{k}$ 
$\mathrm{Fe}_{3} \mathrm{O}_{4}$ surface to enhance organic compounds degradation. ${ }^{\mathbf{1 3 - 1 6}}$ These results showed a significant increase in activity for the oxidation of organics due to a thermodynamically favorable electron transfer from $\mathrm{Fe}^{0}$ to $\mathrm{Fe}_{3} \mathrm{O}_{4}$ producing active $\mathrm{Fe}^{2+}$ species. More recently, to achieve better catalytic activity, ironcopper bimetallic catalyst system has also attracted increasing attention. ${ }^{17,18}$ The combination of copper with iron exhibits an improved catalytic activity due to the synergic effects of twometal redox couples. For instance, Wang et al. synthesized iron-copper bimetallic nanoparticles embedded within ordered mesoporous carbon (CuFe-MC) and observed a greater catalytic activity of CuFe-MC than those of Fe-MC and $\mathrm{Cu}-\mathrm{MC} .{ }^{17}$ The reactions in Fenton-like system with iron-copper bimetallic nanoparticles were described by the following equations: ${ }^{17,18}$

$$
\begin{gathered}
\equiv \mathrm{Fe}^{0}+2 \mathrm{H}^{+} \rightarrow \equiv \mathrm{Fe}^{2+}+\mathrm{H}_{2} \\
\equiv \mathrm{Fe}^{0}+\mathrm{H}_{2} \mathrm{O}_{2}+2 \mathrm{H}^{+} \rightarrow \equiv \mathrm{Fe}^{2+}+2 \mathrm{H}_{2} \mathrm{O} \\
2 \equiv \mathrm{Cu}^{0}+\mathrm{H}_{2} \mathrm{O}_{2}+2 \mathrm{H}^{+} \rightarrow 2 \equiv \mathrm{Cu}^{+}+2 \mathrm{H}_{2} \mathrm{O} \\
\equiv \mathrm{Fe}^{2+}+\mathrm{H}_{2} \mathrm{O}_{2} \rightarrow \equiv \mathrm{Fe}^{3+}+\cdot \mathrm{OH}+\mathrm{OH}^{-} \\
\equiv \mathrm{Fe}^{3+}+\mathrm{H}_{2} \mathrm{O}_{2} \rightarrow \equiv \mathrm{Fe}^{2+}+\cdot \mathrm{O}_{2} \mathrm{H}+\mathrm{H}^{+} \\
\equiv \mathrm{Cu}^{+}+\mathrm{H}_{2} \mathrm{O}_{2} \rightarrow \equiv \mathrm{Cu}^{2+}+\cdot \mathrm{OH}^{-} \mathrm{OH}^{-} \\
\equiv \mathrm{Cu}^{2+}+\mathrm{H}_{2} \mathrm{O}_{2} \rightarrow \equiv \mathrm{Cu}^{+}+\cdot \mathrm{O}_{2} \mathrm{H}+\mathrm{H}^{+} \\
\equiv \mathrm{Fe}^{3+}+\equiv \mathrm{Cu}^{+} \rightarrow \equiv \mathrm{Fe}^{2+}+\equiv \mathrm{Cu}^{2+} \\
\equiv \mathrm{Fe}^{0}+2 \equiv \mathrm{Fe}^{3+} \rightarrow 3 \equiv \mathrm{Fe}^{2+}
\end{gathered}
$$

Therefore, to increase the catalytic activity of $\mathrm{CuFe}_{2} \mathrm{O}_{4}$, the surface modification of $\mathrm{CuFe}_{2} \mathrm{O}_{4}$ by introducing $\mathrm{Fe}^{0}$ and $\mathrm{Cu}^{0}$ was proposed in this study.

In this work, we used $\mathrm{H}_{2}$ to reduce $\mathrm{CuFe}_{2} \mathrm{O}_{4}$ and obtained zero-valent iron-copper bimetallic particles on the surface of $\mathrm{CuFe}_{2} \mathrm{O}_{4}$. The reduced $\mathrm{CuFe}_{2} \mathrm{O}_{4}$ was then used as Fenton-like catalyst. The overarching goal of this study was to develop a powerful candidate of heterogeneous Fenton-like catalyst. Methylene blue (MB) was selected as a model compound for dyes. The common influencing parameters on MB degradation were comprehensively investigated. The magnetic separation and regeneration of reduced $\mathrm{CuFe}_{2} \mathrm{O}_{4}$ were performed. Finally, the possible catalytic mechanism was also discussed.

\section{Materials and methods}

\subsection{Materials}

$\mathrm{H}_{2} \mathrm{O}_{2}(30 \%, w / w)$ was of analytical grade and was supplied by Sinopharm Chemical Reagent Co. (Shanghai, China). Other chemicals (analytical grade) used in the study were purchased from Sigma-Aldrich and used without further purification. All solutions were prepared using $18 \mathrm{M} \Omega$ deionized $\mathrm{H}_{2} \mathrm{O}$ at neutral $\mathrm{pH}$ (Millipore, USA). The stock solutions containing $250 \mathrm{mg} \mathrm{L}^{-1}$ of $\mathrm{MB}$ were freshly prepared by dissolving appropriate amounts of $\mathrm{MB}$ and kept in the dark.

\subsection{Preparation of reduced $\mathrm{CuFe}_{2} \mathrm{O}_{4}$}

The $\mathrm{CuFe}_{2} \mathrm{O}_{4}$ was synthesized in classical alkaline medium using conventional literature recipes. ${ }^{19}$ In brief, $0.025 \mathrm{~mol}$ $\mathrm{CuCl}_{2} \cdot 2 \mathrm{H}_{2} \mathrm{O}$ and $0.05 \mathrm{~mol} \mathrm{FeCl} \cdot 6 \mathrm{H}_{2} \mathrm{O}$ were dissolved together in $100 \mathrm{~mL}$ of deionized $\mathrm{H}_{2} \mathrm{O}$, and then $75 \mathrm{~mL} \mathrm{NaOH}$ solution (4 $\mathrm{M})$ was added dropwise, followed by heating at $90{ }^{\circ} \mathrm{C}$. The black precipitate was homogenized by vigorous stirring for $2 \mathrm{~h}$ at $90{ }^{\circ} \mathrm{C}$ and then washed by deionized water several times, until the water $\mathrm{pH}$ did not change. Finally, the $\mathrm{CuFe}_{2} \mathrm{O}_{4}$ was filtrated and dried at $70{ }^{\circ} \mathrm{C}$ overnight followed by calcination in flowing air at $400{ }^{\circ} \mathrm{C}$ for $4 \mathrm{~h}$.

The reduced $\mathrm{CuFe}_{2} \mathrm{O}_{4}$ was prepared by thermal treatment at $400{ }^{\circ} \mathrm{C}$ in a quartz tube under $\mathrm{H}_{2}(99.99 \%)$ flow $\left(30 \mathrm{~mL} \mathrm{~min}{ }^{-1}\right.$ ) for $4 \mathrm{~h}$ with a heating rate of $10{ }^{\circ} \mathrm{C} \mathrm{min}^{-1}$. After reduction, the material was cooled down under $\mathrm{H}_{2}$ flow to room temperature and was transferred to a sample vial and kept sealed under nitrogen atmosphere prior to use.

\subsection{Characterization}

Transmission electron micrograph (TEM) of the samples was taken on a Hitachi H-8100 TEM, operated at $200 \mathrm{kV}$. Powder Xray diffraction (XRD) patterns were recorded on a Philips PW1710 diffractometer using $\mathrm{Cu} \mathrm{K} \alpha$ radiation. Nitrogen adsorption-desorption isotherms were measured at $77 \mathrm{~K}$ on a Micromeritics ASAP 2020 sorptometer, with the samples outgassed for $16 \mathrm{~h}$ at $110^{\circ} \mathrm{C}$ and $10^{-6}$ Torr prior to measurement. $\mathrm{X}$ ray photoelectron spectroscopy (XPS) of the above mentioned samples were recorded on a spectrometer (Perkin-Elmer PHI5300/ESCA, USA) with an Al K $\alpha$ X-ray source. All the binding energies were referenced to the neutral C 1 s peak at $284.6 \mathrm{eV}$ to compensate for the surface charging effects. The XPS results were collected as binding energy forms and fitted using a curvefitting program (XPSPEAK41 software).

\subsection{Experimental procedure}

Batch degradation experiments of $\mathrm{MB}$ were carried out in a $100 \mathrm{~mL}$ conical flask at $25{ }^{\circ} \mathrm{C}$ in the dark. The initial concentration of $\mathrm{MB}$ was $50 \mathrm{mg} \mathrm{\textrm {L } ^ { - 1 }}$, and the total volume of reaction solution was $50 \mathrm{~mL}$. The reaction suspension was prepared by adding the required amount of catalyst into $50 \mathrm{~mL}$ solution that had been adjusted to the desired $\mathrm{pH}$ value by $0.1 \mathrm{M} \mathrm{HNO}_{3}$. A known concentration of $\mathrm{H}_{2} \mathrm{O}_{2}$ was added to the solution to initiate the reaction. Samples were taken at set intervals using a $1 \mathrm{~mL}$ syringe, and quenched with excess methanol. To evaluate the contribution of homogeneous Fenton catalyzed by the leaching $\mathrm{Fe}$ and $\mathrm{Cu}$ ions on the $\mathrm{MB}$ degradation, experiment was carried out as follows: after mixing reduced $\mathrm{CuFe}_{2} \mathrm{O}_{4}$ at solution pH 3.2 for 25 min and removing the catalyst by filtration, MB and $\mathrm{H}_{2} \mathrm{O}_{2}$ were then added into the filtrate. The reusability of the catalyst was evaluated by collecting the catalyst with a magnet, washing with deionized water, drying the used catalyst under vacuum, and using it for the next reaction under similar experimental conditions. The catalytic activities were calculated by the concentration of $\mathrm{MB}\left(C / C_{0}\right)$, where $C_{0}$ and $C$ were the $\mathrm{MB}$ concentrations at initial and time $t$, respectively. 

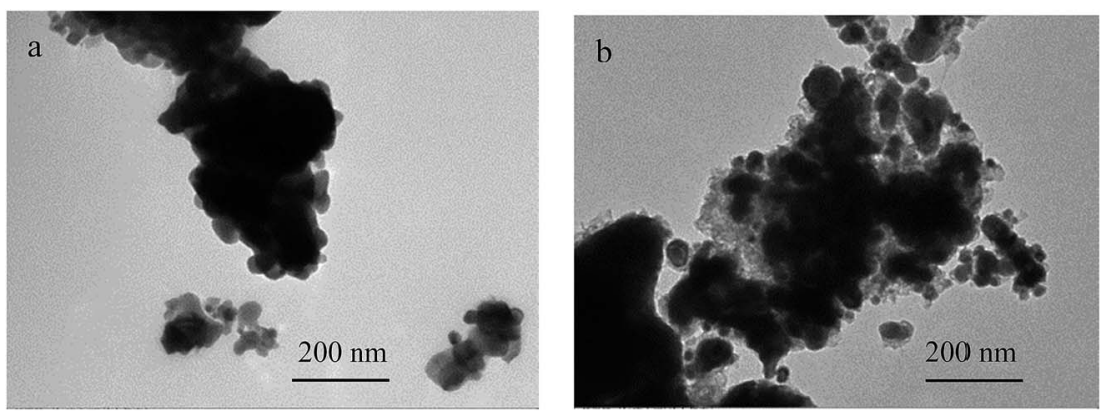

Fig. 1 TEM images of (a) $\mathrm{CuFe}_{2} \mathrm{O}_{4}$ and (b) reduced $\mathrm{CuFe}_{2} \mathrm{O}_{4}$.

\section{Results and discussion}

\subsection{Characterization}

The transmission electron microscope (TEM) images of the $\mathrm{CuFe}_{2} \mathrm{O}_{4}$ and reduced $\mathrm{CuFe}_{2} \mathrm{O}_{4}$ are shown in Fig. 1 . It can be seen that $\mathrm{CuFe}_{2} \mathrm{O}_{4}$ had a relatively smooth nonporous surface and reduced $\mathrm{CuFe}_{2} \mathrm{O}_{4}$ had fluffy appearance. The specific surface area (SSA) of $\mathrm{CuFe}_{2} \mathrm{O}_{4}$ and reduced $\mathrm{CuFe}_{2} \mathrm{O}_{4}$ was obtained from the $\mathrm{N}_{2}$ adsorption-desorption isotherms (Fig. S1a $\dagger$ ). It can be seen that both the isotherms could be classified as type IV based on the IUPAC classification scheme. The SSA was measured to be $15.6 \mathrm{~m}^{2} \mathrm{~g}^{-1}$ for $\mathrm{CuFe}_{2} \mathrm{O}_{4}$ and 51.8 $\mathrm{m}^{2} \mathrm{~g}^{-1}$ for reduced $\mathrm{CuFe}_{2} \mathrm{O}_{4}$, respectively. The pore size distribution showed that there was a significant increase in volume of pores ranged from 2 to $8 \mathrm{~nm}$ after $\mathrm{H}_{2}$ reduction (Fig. $\mathrm{S} 1 \mathrm{~b} \dagger$ ).

The X-ray diffraction patterns of $\mathrm{CuFe}_{2} \mathrm{O}_{4}$ and reduced $\mathrm{CuFe}_{2} \mathrm{O}_{4}$ are presented in Fig. 2. In the pattern of the $\mathrm{CuFe}_{2} \mathrm{O}_{4}$, all of the diffraction peaks matched well with the standard XRD pattern (PDF \#77-0010), which indicated that the prepared $\mathrm{CuFe}_{2} \mathrm{O}_{4}$ had great purity. In the pattern of the reduced $\mathrm{CuFe}_{2} \mathrm{O}_{4}$, the (110) and (200) diffractions of Fe (PDF \#99-0064) and (200) and (220) diffractions of $\mathrm{Cu}$ (PDF \#70-3039) can be observed simultaneously, indicating the successful loading of $\mathrm{Fe}^{0}$ and $\mathrm{Cu}^{0}$ bimetallic particles in the reduced $\mathrm{CuFe}_{2} \mathrm{O}_{4}$.

Surface elemental composition of $\mathrm{CuFe}_{2} \mathrm{O}_{4}$ and reduced $\mathrm{CuFe}_{2} \mathrm{O}_{4}$ is analyzed by the use of XPS (Fig. 3). In Fig. 3a, the

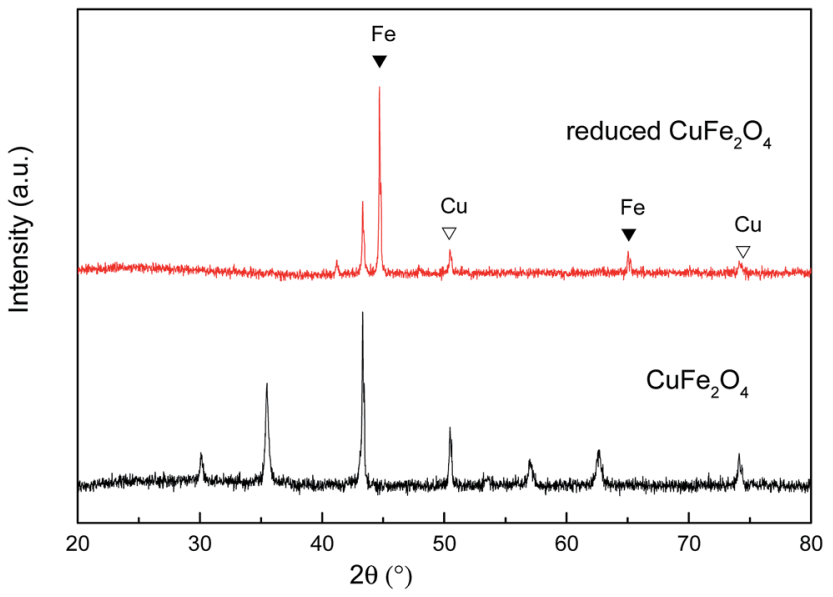

Fig. 2 XRD patterns of $\mathrm{CuFe}_{2} \mathrm{O}_{4}$ and reduced $\mathrm{CuFe}_{2} \mathrm{O}_{4}$. binding energy at $711 \mathrm{eV}$ and $725 \mathrm{eV}$ can be ascribed to Fe $2 \mathrm{p}_{3 / 2}$ and $\mathrm{Fe} 2 \mathrm{p}_{1 / 2}$ according to previous study. ${ }^{20}$ The presence of the peak around 710.1 and $712.0 \mathrm{eV}$ (for $\mathrm{CuFe}_{2} \mathrm{O}_{4}$ ) suggested that $\mathrm{Fe}^{3+}$ existed in two coordination environments where A-sites at higher binding energy and B-sites at lower binding energy, respectively. ${ }^{21}$ After redox reaction, the presence of a $\mathrm{Fe}^{0}$ peak with weak intensity at $706.1 \mathrm{eV}$ was further evidence for the loading of $\mathrm{Fe}^{0}$ in the reduced $\mathrm{CuFe}_{2} \mathrm{O}_{4} \cdot{ }^{22}$ For the XPS of $\mathrm{Cu} 2 \mathrm{p}$ regions (Fig. 3b), the peak at binding energy of $932.5 \mathrm{eV}$ for the reduced $\mathrm{CuFe}_{2} \mathrm{O}_{4}$ was assigned to $\mathrm{Cu}^{0}$, which further confirmed the formation of $\mathrm{Cu}^{0}$ phase in the reduced $\mathrm{CuFe}_{2} \mathrm{O}_{4} \cdot{ }^{23}$ The surface of the reduced $\mathrm{CuFe}_{2} \mathrm{O}_{4}$ samples contained $2.2 \% \mathrm{Fe}^{0}$ and $10.6 \% \mathrm{Cu}^{0}$ based on XPS analysis.

\subsection{Catalytic activity of reduced $\mathrm{CuFe}_{2} \mathrm{O}_{4}$}

Batch experiments were conducted to compare the removal efficiencies of MB by various processes. As shown in Fig. 4, $\mathrm{CuFe}_{2} \mathrm{O}_{4}$ exhibited relatively low catalytic activity and only $20 \%$ of $\mathrm{MB}$ was decoloured after $25 \mathrm{~min}$. By contrast, $\mathrm{MB}$ was rapidly degraded by reduced $\mathrm{CuFe}_{2} \mathrm{O}_{4}$ and greater than $74 \%$ of $\mathrm{MB}$ was destructed within $25 \mathrm{~min}$ at $0.5 \mathrm{mM} \mathrm{H}_{2} \mathrm{O}_{2}$ and $0.1 \mathrm{~g} \mathrm{~L}^{-1}$ catalyst dosage. Meanwhile, $\mathrm{H}_{2} \mathrm{O}_{2}$ alone showed no remarkable degradation of $\mathrm{MB}$ and less than $7 \%$ of $\mathrm{MB}$ was adsorbed onto reduced $\mathrm{CuFe}_{2} \mathrm{O}_{4}$. The kinetic data were then fitted to a pseudofirst-order kinetic model $\left(C=C_{0} \mathrm{e}^{-k t}\right)$. The Fenton-like reaction rate $k\left(\mathrm{~min}^{-1}\right)$ was calculated to be $0.007\left(R^{2}=0.87\right)$ and 0.055 $\left(R^{2}=0.98\right) \min ^{-1}$ for $\mathrm{CuFe}_{2} \mathrm{O}_{4}$ and reduced $\mathrm{CuFe}_{2} \mathrm{O}_{4}$, respectively. These results clearly indicate that the catalytic activity of $\mathrm{CuFe}_{2} \mathrm{O}_{4}$ is significantly enhanced after $\mathrm{H}_{2}$ reduction. One possible reason was the increased SSA, which provided more active sites for $\mathrm{H}_{2} \mathrm{O}_{2}$ decomposition and produced more reactive oxidants such as ${ }^{\circ} \mathrm{OH}$. The other possible reason was the introduction of $\mathrm{Fe}^{0}$ and $\mathrm{Cu}^{0}$, which could facilitate the decomposition of $\mathrm{H}_{2} \mathrm{O}_{2}$ into ${ }^{\circ} \mathrm{OH}$ and accelerate electron transfer from $\mathrm{Fe}^{0}$ and/or $\mathrm{Cu}^{0}$ to $\mathrm{CuFe}_{2} \mathrm{O}_{4} \cdot{ }^{16,24}$

To better understand the contribution of homogeneous Fenton reaction catalyzed by the leaching $\mathrm{Fe}$ and $\mathrm{Cu}$ ions on the MB degradation, experiment in homogeneous systems was carried out by removing reduced $\mathrm{CuFe}_{2} \mathrm{O}_{4}$ catalyst after vigorous agitation for $25 \mathrm{~min}$. As shown in Fig. 4, the removal of MB after a reaction period of $25 \mathrm{~min}$ in the homogeneous Fenton-like reaction system was $52 \%$. By contrast, the removal of MB catalyzed by reduced $\mathrm{CuFe}_{2} \mathrm{O}_{4}$ at 25 min was $74 \%$. These results 

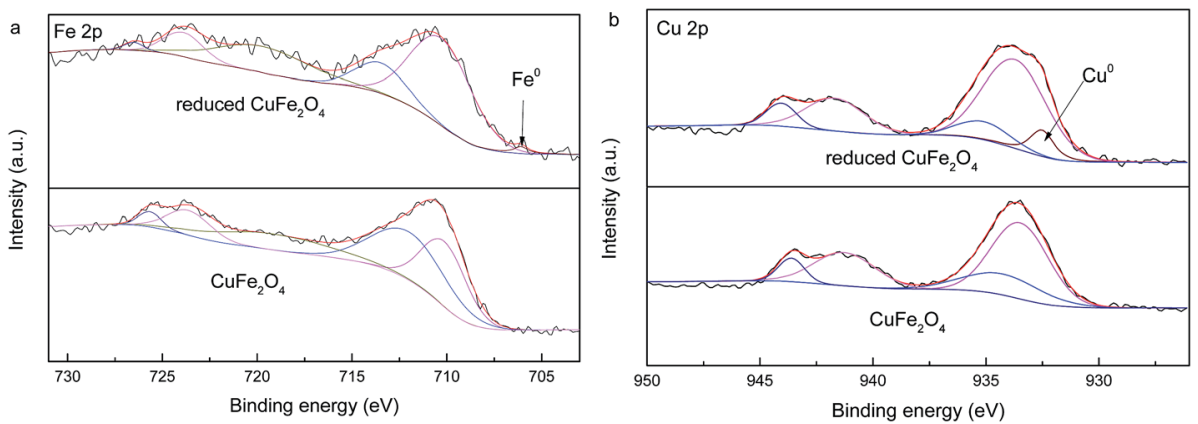

Fig. 3 XPS spectra for Fe $2 p(a)$ and $\mathrm{Cu} 2 p(b)$ of $\mathrm{CuFe}_{2} \mathrm{O}_{4}$ and reduced $\mathrm{CuFe}_{2} \mathrm{O}_{4}$

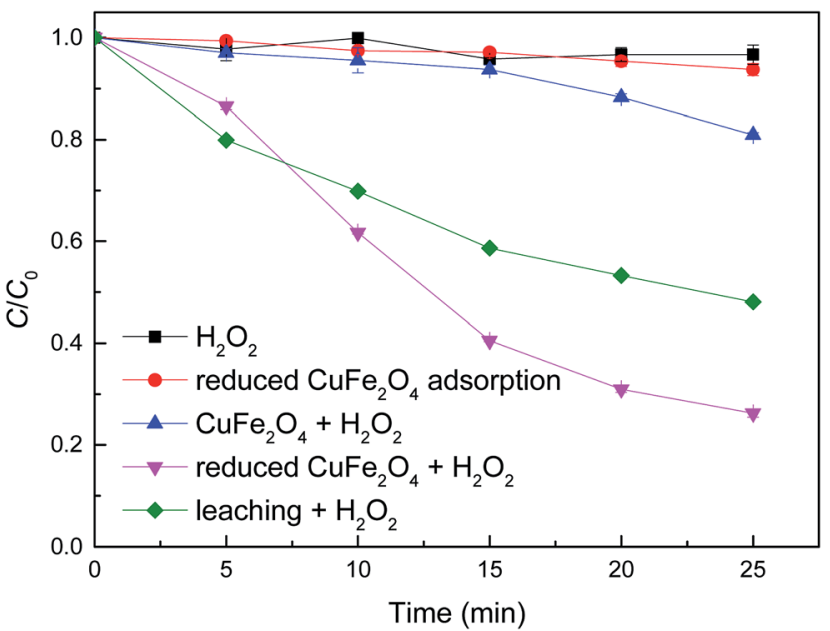

Fig. 4 Comparison of the removal efficiency of $M B$ with different catalytic systems. Conditions: $\left[\mathrm{H}_{2} \mathrm{O}_{2}\right]=0.5 \mathrm{mM}$, catalyst dosage $=$ $0.1 \mathrm{~g} \mathrm{~L}^{-1},[\mathrm{MB}]=50 \mathrm{mg} \mathrm{L}^{-1}$, initial $\mathrm{pH}=3.2 \pm 0.1$.

suggest that the removal of MB was attributed by both the homogeneous and heterogeneous Fenton-like reactions. Similar results were also obtained by Fenton-like degradation of 2,4-dichlorophenol using $\mathrm{Fe}_{3} \mathrm{O}_{4}$ magnetic nanoparticles, which assumed that the removal of 2,4-dichlorophenol was partially attributed to the bulk homogeneous Fenton reaction due to the dissolved Fe ions. ${ }^{6}$ The leached ions were determined in our study and the concentrations of total dissolved $\mathrm{Fe}$ and $\mathrm{Cu}$ were 0.49 and $1.09 \mathrm{mg} \mathrm{L}^{-1}$ after a reaction period of $25 \mathrm{~min}$.

A comparison was carried out between the reaction rate constant of reduced $\mathrm{CuFe}_{2} \mathrm{O}_{4}$ with those reported in previous studies. ${ }^{25-31}$ Based on the obtained results (Table S1 $\dagger$ ), it seems that the proposed heterogeneous Fenton-like system leads to a high efficiency for MB degradation.

\subsection{Effects of parameters on MB degradation}

The degradation of organic pollutants was usually influenced by $\mathrm{pH}$, catalyst dosage and $\mathrm{H}_{2} \mathrm{O}_{2}$ concentration. The degradation of $\mathrm{MB}$ over time under different experimental conditions was evaluated.

Fig. 5 shows the effect of $\mathrm{pH}$ on the removal of $\mathrm{MB}$ by reduced $\mathrm{CuFe}_{2} \mathrm{O}_{4}$. It can be seen that $\mathrm{pH}$ had a distinct influence on the removal of $\mathrm{MB}$ by Fenton-like reaction. The relatively slow degradation of $\mathrm{MB}$ was observed at $\mathrm{pH}$ values of 4.5 and 6.0, while a lower $\mathrm{pH}$ induced a higher kinetic rate. The increased oxidation efficiency at lower $\mathrm{pH}$ values can be attributed to the higher oxidation potential of ${ }^{\circ} \mathrm{OH}$ and the more dissolved fraction of iron species. ${ }^{12}$ It was also proposed that acidic conditions were favourable for the stability of $\mathrm{H}_{2} \mathrm{O}_{2}$ and were beneficial for the generation of ${ }^{\circ} \mathrm{OH}$ and the formation of metal oxide-pollutant inner-sphere complexes that will promote reaction. ${ }^{6}$ On the other hand, as $\mathrm{Fe}^{0}$ and $\mathrm{Cu}^{0}$ were loaded on the surface of reduced $\mathrm{CuFe}_{2} \mathrm{O}_{4}$, the lower $\mathrm{pH}$ will favor the generation of $\mathrm{Fe}^{2+}$ and $\mathrm{Cu}^{+}$(eqn (1)-(3)), which could promote the decomposition of $\mathrm{H}_{2} \mathrm{O}_{2}$ into ${ }^{\circ} \mathrm{OH}$ (eqn (4) and (6)). ${ }^{32}$

Fig. 6 shows the degradation of $\mathrm{MB}$ by reduced $\mathrm{CuFe}_{2} \mathrm{O}_{4}$ at different catalyst dosages. It can be observed that the removal of MB by degradation increased along with increasing catalyst dosages. The degradation of MB achieved $59.4 \%$ with $0.05 \mathrm{~g} \mathrm{~L}^{-1}$ catalyst dosage, and up to $73.8 \%$ when the catalyst dosage increased to $0.1 \mathrm{~g} \mathrm{~L}^{-1}$. This finding was likely attributed to the increased amount of active sites on the solid catalyst surface, which was expected to accelerate the reactions of $\mathrm{H}_{2} \mathrm{O}_{2}$ decomposition. Moreover, increasing catalyst dosage could result in a higher iron dissolution, and ultimately producing

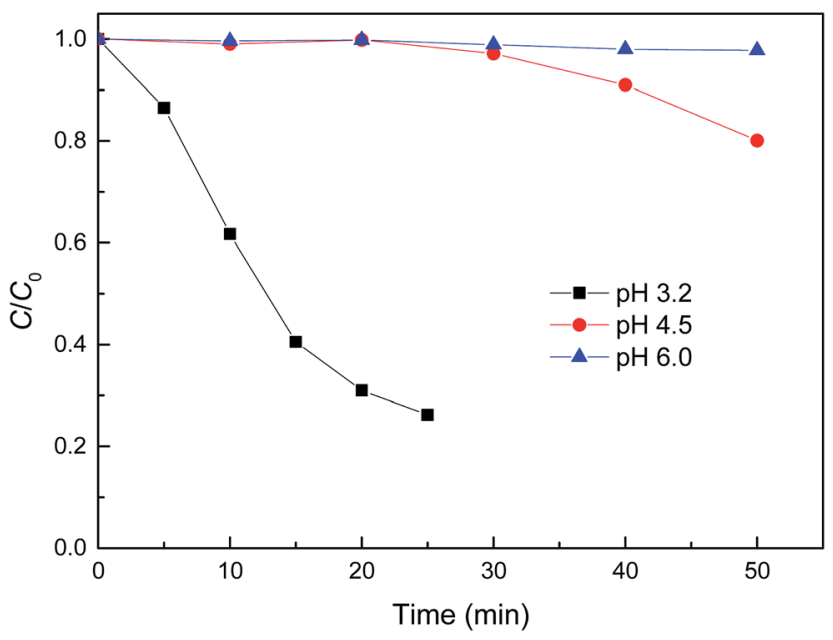

Fig. 5 Effect of initial $\mathrm{pH}$ on $\mathrm{MB}$ degradation by reduced $\mathrm{CuFe}_{2} \mathrm{O}_{4}$. Conditions: $\left[\mathrm{H}_{2} \mathrm{O}_{2}\right]=0.5 \mathrm{mM}$, [reduced $\left.\mathrm{CuFe}_{2} \mathrm{O}_{4}\right]=0.1 \mathrm{~g} \mathrm{~L}^{-1},[\mathrm{MB}]=$ $50 \mathrm{mg} \mathrm{L}^{-1}$. 


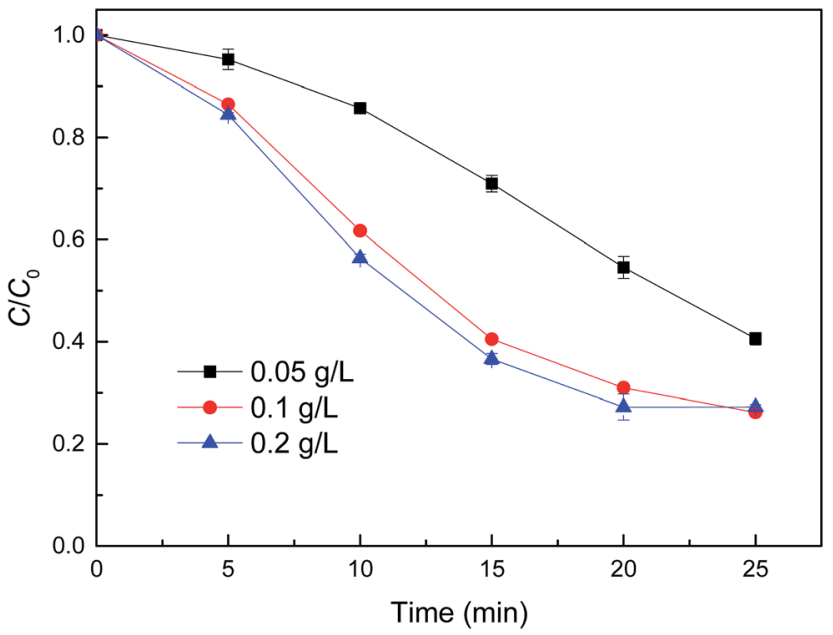

Fig. 6 Effect of catalyst dose on $\mathrm{MB}$ degradation by reduced $\mathrm{CuFe}_{2} \mathrm{O}_{4}$. Conditions: $\left[\mathrm{H}_{2} \mathrm{O}_{2}\right]=0.5 \mathrm{mM},[\mathrm{MB}]=50 \mathrm{mg} \mathrm{L}^{-1}$, initial $\mathrm{pH}=3.2 \pm 0.1$.

more radicals. However, when reduced $\mathrm{CuFe}_{2} \mathrm{O}_{4}$ addition increased to $0.2 \mathrm{~g} \mathrm{~L}^{-1}$, the degradation of $\mathrm{MB}$ was not further enhanced, probably due to the agglomeration of particles and the scavenging of ${ }^{\circ} \mathrm{OH}$ or other radicals by present iron species through undesirable reactions. ${ }^{\mathbf{1 2}}$

The effect of $\mathrm{H}_{2} \mathrm{O}_{2}$ concentration on the removal of $\mathrm{MB}$ using reduced $\mathrm{CuFe}_{2} \mathrm{O}_{4}$ was also investigated (Fig. 7). It was observed clearly that the degradation of $\mathrm{MB}$ was gradually accelerated with $\mathrm{H}_{2} \mathrm{O}_{2}$ concentration increasing from 0.2 to $1.0 \mathrm{mM}$. This positive correlation could be related to the accelerated generation of oxidizing intermediates that were responsible for $\mathrm{MB}$ oxidation, when considering that $\mathrm{H}_{2} \mathrm{O}_{2}$ alone had a negligible degradation effect on $\mathrm{MB}$. It was proposed that $\mathrm{H}_{2} \mathrm{O}_{2}$ is the precursor in the reaction with $\equiv \mathrm{Fe}^{2+}$ generating ${ }^{\circ} \mathrm{OH} \cdot{ }^{33}$ With sufficient $\mathrm{H}_{2} \mathrm{O}_{2}$, the amount of ${ }^{\circ} \mathrm{OH}$ generated will be enhanced, leading to a high removal efficiency of MB.

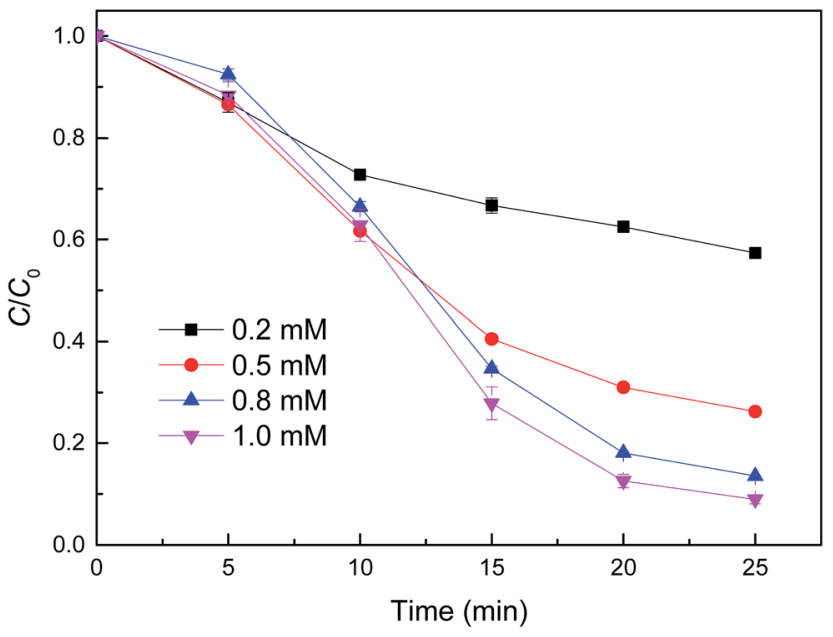

Fig. 7 Effect of $\mathrm{H}_{2} \mathrm{O}_{2}$ concentration on $\mathrm{MB}$ degradation by reduced $\mathrm{CuFe}_{2} \mathrm{O}_{4}$. Conditions: [reduced $\mathrm{CuFe}_{2} \mathrm{O}_{4}$ ] $=0.1 \mathrm{~g} \mathrm{~L}^{-1}$, [MB] = $50 \mathrm{mg} \mathrm{L}^{-1}$, initial $\mathrm{pH}=3.2 \pm 0.1$.

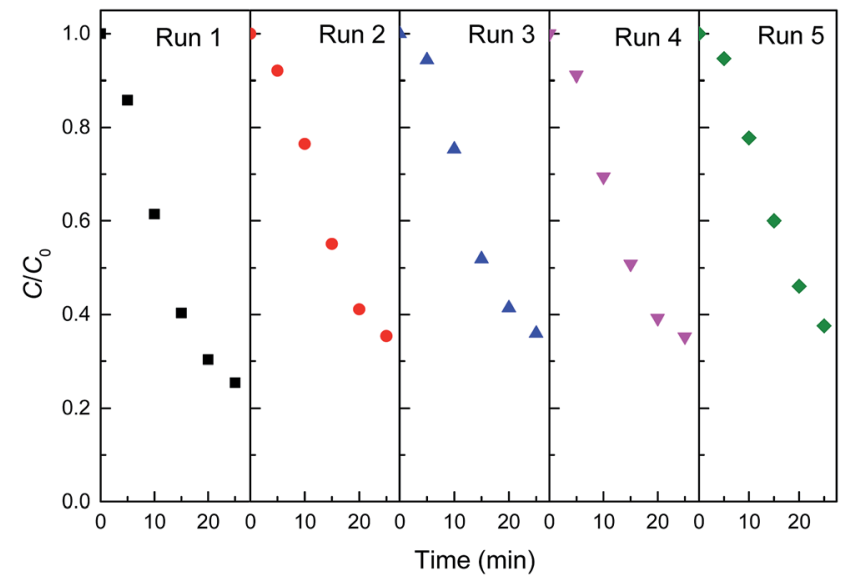

Fig. 8 Degradation of $\mathrm{MB}$ in different batch runs in the reduced $\mathrm{CuFe}_{2} \mathrm{O}_{4} / \mathrm{H}_{2} \mathrm{O}_{2}$ system.

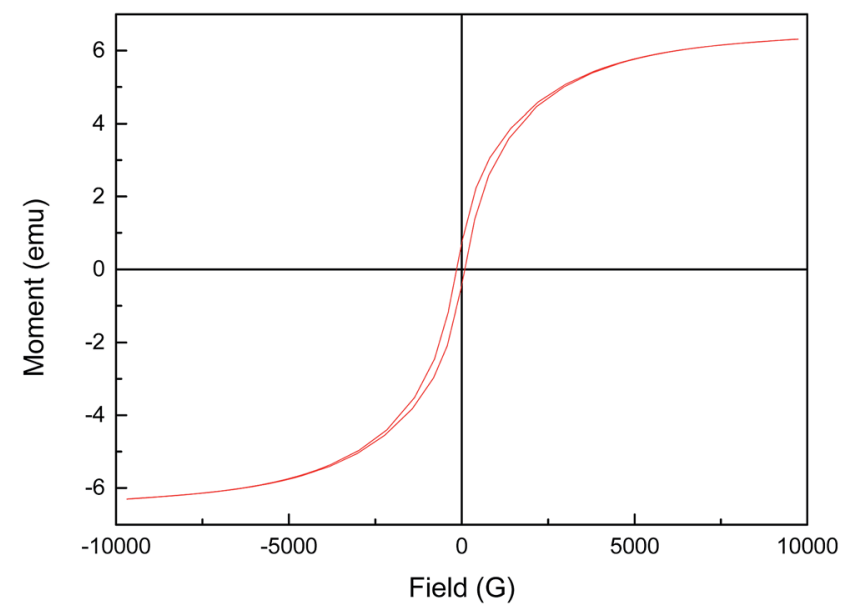

Fig. 9 Magnetization curve of reduced $\mathrm{CuFe}_{2} \mathrm{O}_{4}$.

\subsection{Stability and reusability of reduced $\mathrm{CuFe}_{2} \mathrm{O}_{4}$}

Stability is an important factor for the application of catalyst in heterogeneous Fenton-like reaction. From the view of practical application, the long term stability of reduced $\mathrm{CuFe}_{2} \mathrm{O}_{4}$ is crucial. Therefore, the leaching characteristic and the activity variation of reduced $\mathrm{CuFe}_{2} \mathrm{O}_{4}$ in cycles are especially concerned. The leaching ions were determined and the concentration of total dissolved iron and copper were 0.49 and $1.09 \mathrm{mg} \mathrm{L}^{-1}$ after 25 min reaction. This phenomenon partially confirmed the stability of catalyst. Successive experiments were performed to evaluate the possibility of reduced $\mathrm{CuFe}_{2} \mathrm{O}_{4}$ reuse. As shown in Fig. 8, it was observed that reduced $\mathrm{CuFe}_{2} \mathrm{O}_{4}$ remained a high catalytic activity after five consecutive runs. The XRD pattern of the catalyst after five cycles showed that crystal phase of the used catalyst was almost the same as that of the fresh catalyst (Fig. S2 $\dagger$ ). These results demonstrate that reduced $\mathrm{CuFe}_{2} \mathrm{O}_{4}$ has a high stability and a good reusability after the recycling tests, suggesting the feasibility of the reduced $\mathrm{CuFe}_{2} \mathrm{O}_{4} / \mathrm{H}_{2} \mathrm{O}_{2}$ system for a longer reaction time. 


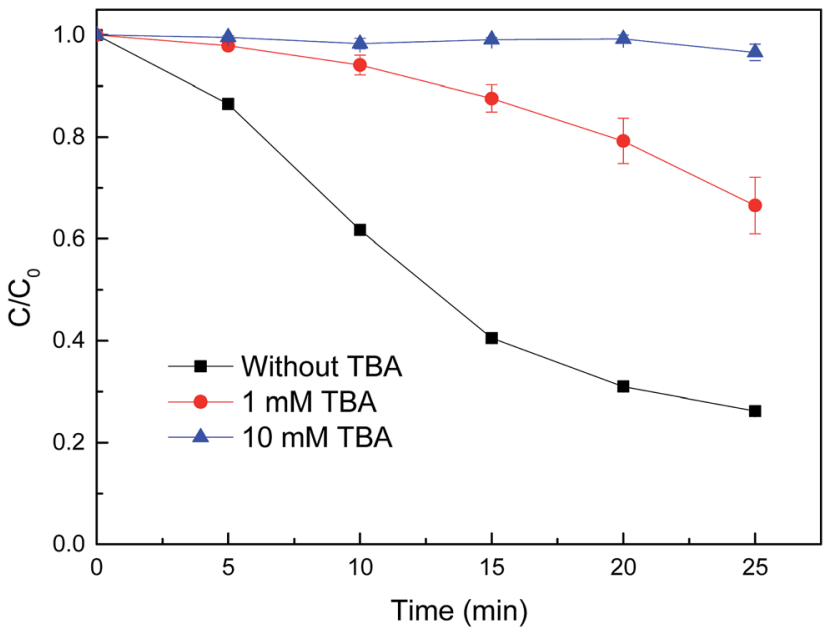

Fig. 10 Effect of TBA on $\mathrm{MB}$ degradation by reduced $\mathrm{CuFe}_{2} \mathrm{O}_{4}$. Conditions: $\left[\mathrm{H}_{2} \mathrm{O}_{2}\right]=0.5 \mathrm{mM}$, [reduced $\left.\mathrm{CuFe}_{2} \mathrm{O}_{4}\right]=0.1 \mathrm{~g} \mathrm{~L}^{-1}$, $[\mathrm{MB}]=$ $50 \mathrm{mg} \mathrm{L}^{-1}$, initial $\mathrm{pH}=3.2 \pm 0.1$.

The magnetization curves of reduced $\mathrm{CuFe}_{2} \mathrm{O}_{4}$ were investigated by vibrating sample magnetometer (VSM) at $25^{\circ} \mathrm{C}$ and the results were illustrated in Fig. 9. The magnetic hysteresis curve revealed that reduced $\mathrm{CuFe}_{2} \mathrm{O}_{4}$ was ferromagnetic and had a magnetic saturation of about $6.3 \mathrm{emu}^{-1}$, which ensured that the catalyst could be easily separated by a magnet and reused from aqueous solution.

\subsection{The enhanced reaction mechanism}

In order to discriminate the active species in the reduced $\mathrm{CuFe}_{2} \mathrm{O}_{4} / \mathrm{H}_{2} \mathrm{O}_{2}$ system for $\mathrm{MB}$ degradation, tert-butyl alcohol (TBA) was used as the scavenger of ${ }^{\circ} \mathrm{OH}$ in this study. As shown in Fig. 10, the degradation efficiency of MB decreased from $75 \%$ without inhibitor to 34 and $3 \%$ with the addition of 1 and $10 \mathrm{mM}$ TBA, respectively. There was almost no MB degradation with the addition of $10 \mathrm{mM}$ TBA during the reaction, indicating that the ${ }^{\circ} \mathrm{OH}$ produced by $\mathrm{H}_{2} \mathrm{O}_{2}$ in the Fenton-like reaction was

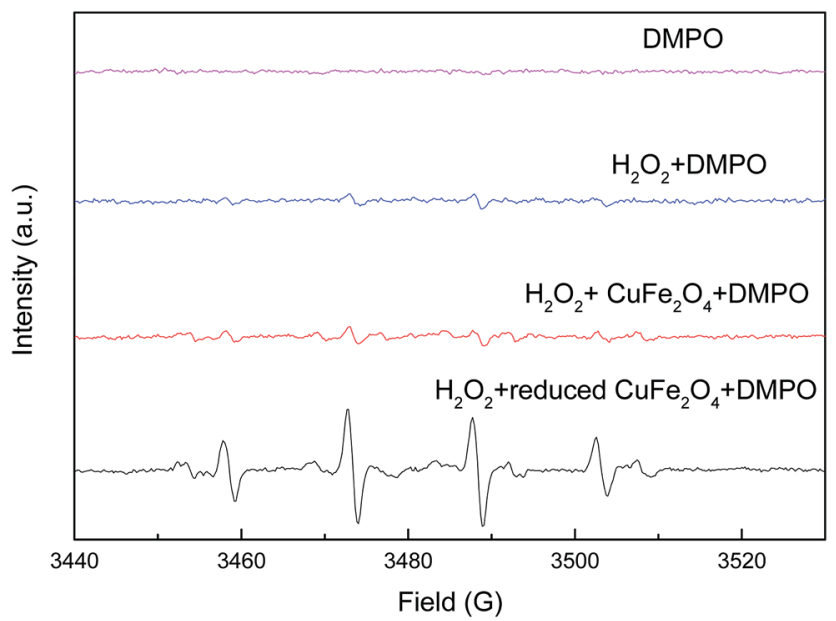

Fig. 11 DMPO spin trapping ESR spectra of ${ }^{\circ} \mathrm{OH}$ in the systems. scavenged. These results indicate that MB is mainly decomposed by the attack of ${ }^{\circ} \mathrm{OH}$.

To ascertain the reaction mechanism, electron spin resonance (ESR) spectroscopy was performed by using 5,5-dimethyl1-pyrroline- $N$-oxide (DMPO) as trapping agent to examine ${ }^{\circ} \mathrm{OH}$ produced in the heterogeneous Fenton-like reaction. As shown in Fig. 11, the ESR spectrum in the presence of catalysts displayed a 4 -fold characteristic peak of DMPO- ${ }^{-} \mathrm{OH}$ adduct with an intensity ratio of $1: 2: 2: 1$. The intensity of $\mathrm{DMPO}-^{-} \mathrm{OH}$ peaks by using reduced $\mathrm{CuFe}_{2} \mathrm{O}_{4}$ as catalyst was much stronger than $\mathrm{CuFe}_{2} \mathrm{O}_{4}$, demonstrating a high catalytic activity in the reduced $\mathrm{CuFe}_{2} \mathrm{O}_{4} / \mathrm{H}_{2} \mathrm{O}_{2}$ system. Therefore, it can be concluded that reduced $\mathrm{CuFe}_{2} \mathrm{O}_{4}$ could effectively activate $\mathrm{H}_{2} \mathrm{O}_{2}$ to generate ${ }^{\circ} \mathrm{OH}$ and the ${ }^{\circ} \mathrm{OH}$ was the predominant active radical in the heterogeneous Fenton-like reaction.

The above results have shown that the ${ }^{\circ} \mathrm{OH}$ is the major active radical in the heterogeneous Fenton-like processes. Moreover, the enhanced catalytic activity is displayed by catalyst of reduced $\mathrm{CuFe}_{2} \mathrm{O}_{4}$, which shows high MB removal efficiency. The Fenton-like reaction rate $k\left(\mathrm{~min}^{-1}\right)$ was calculated to be 0.007 and $0.055 \mathrm{~min}^{-1}$ for $\mathrm{CuFe}_{2} \mathrm{O}_{4}$ and reduced $\mathrm{CuFe}_{2} \mathrm{O}_{4}$, respectively. When normalized by SSA, the $k / \mathrm{SSA}$ values indicate a higher $\mathrm{MB}$ removal efficiency for the reduced $\mathrm{CuFe}_{2} \mathrm{O}_{4}$ than for the $\mathrm{CuFe}_{2} \mathrm{O}_{4}$. This suggests that $\mathrm{Fe}^{0}$ and $\mathrm{Cu}^{0}$ bimetallic particles loaded in the reduced $\mathrm{CuFe}_{2} \mathrm{O}_{4}$ play important role in the heterogeneous Fenton reaction. According to all above experimental results, a possible mechanism for reduced $\mathrm{CuFe}_{2} \mathrm{O}_{4}$ degradation of $\mathrm{MB}$ has been proposed. In the first step, the $\mathrm{H}_{2} \mathrm{O}_{2}$ molecules can be adsorbed on reduced $\mathrm{CuFe}_{2} \mathrm{O}_{4}$ and react with the metallic particles. Specifically, the $\mathrm{Fe}^{0}$ can be oxidized to $\mathrm{Fe}^{2+}$ via a two electron transfer (eqn (2)) and $\mathrm{Cu}^{0}$ can be oxidized to $\mathrm{Cu}^{+}$via a one electron transfer from the particles surface to $\mathrm{H}_{2} \mathrm{O}_{2}$ (eqn (3)). ${ }^{\mathbf{1 8 , 3 4}}$ These oxidation reactions were further confirmed by the results of XPS (Fig. S3 $\dagger$ ). The peak of $\mathrm{Fe}^{0}$ disappeared after reaction. The atomic ratio of $\mathrm{Cu}^{0}$ decreased from $10.6 \%$ in the fresh catalyst to $4.9 \%$ in the used catalyst.

Then, $\mathrm{Fe}^{2+}$ on the surface participate in the reaction by activating $\mathrm{H}_{2} \mathrm{O}_{2}$ molecules to produce ${ }^{\circ} \mathrm{OH}$ according to the Haber-Weiss mechanism (eqn (4) and (5)). ${ }^{33,35}$ Similarly, $\mathrm{Cu}^{+}$on the surface can also participate in the reaction by activating $\mathrm{H}_{2} \mathrm{O}_{2}$ molecules to generate $\mathrm{OH}$ (eqn (6)). ${ }^{17,18}$ On the other hand, the loading of $\mathrm{Fe}^{0}$ could act as an electron transfer agent during reaction, which could easily reduce $\mathrm{Fe}^{3+}$ species in the

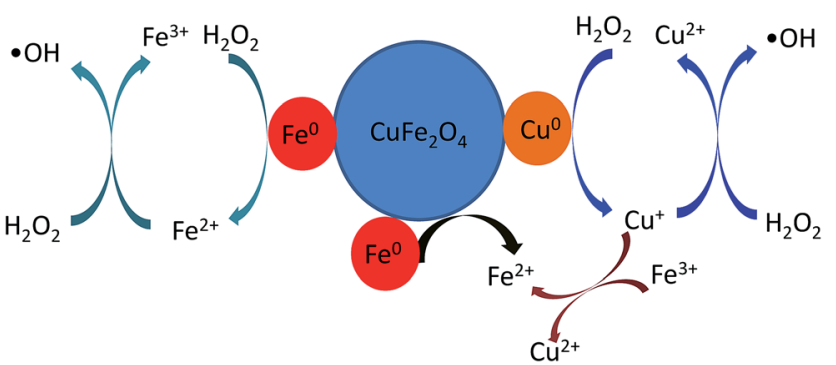

Fig. 12 Schematic diagram of MB degradation mechanism by reduced $\mathrm{CuFe}_{2} \mathrm{O}_{4}$. 
$\mathrm{CuFe}_{2} \mathrm{O}_{4}$ phase to regenerate the active $\mathrm{Fe}^{2+}$ species (eqn (9)). ${ }^{\mathbf{1 3 , 1 5}}$ Since the standard reduction potential of $\mathrm{Fe}^{3+} / \mathrm{Fe}^{2+}$ is $0.77 \mathrm{~V}$ and $\mathrm{Cu}^{2+} / \mathrm{Cu}^{+}$is $0.17 \mathrm{~V}$, the redox cycles of $\mathrm{Fe}^{3+} / \mathrm{Fe}^{2+}$ and $\mathrm{Cu}^{2+} / \mathrm{Cu}^{+}$ are also proposed (eqn (8)). ${ }^{17,18}$ Therefore, based on above analysis, a possible enhanced reaction mechanism of $\mathrm{MB}$ degradation by reduced $\mathrm{CuFe}_{2} \mathrm{O}_{4}$ is proposed as illustrated in Fig. 12.

\section{Conclusions}

Reduced $\mathrm{CuFe}_{2} \mathrm{O}_{4}$ was synthesized and used as a heterogeneous Fenton-like catalyst, which exhibited much higher catalytic activity towards the degradation of $\mathrm{MB}$ in the presence of $\mathrm{H}_{2} \mathrm{O}_{2}$ compared with raw $\mathrm{CuFe}_{2} \mathrm{O}_{4}$. The use of $0.1 \mathrm{~g} \mathrm{~L}^{-1}$ reduced $\mathrm{CuFe}_{2} \mathrm{O}_{4}$ induced nearly $74 \%$ of $\mathrm{MB}$ degradation within $25 \mathrm{~min}$ in the presence of $0.5 \mathrm{mM} \mathrm{H}_{2} \mathrm{O}_{2}$ at initial $\mathrm{pH}$ 3.2. The characterization and experimental results suggested that the high catalytic activity was attributed to the high surface area and the presence of $\mathrm{Fe}^{0} / \mathrm{Cu}^{0}$ bimetallic particles on the surface of reduced $\mathrm{CuFe}_{2} \mathrm{O}_{4}$. The reusability tests indicated that reduced $\mathrm{CuFe}_{2} \mathrm{O}_{4}$ was relatively stable and could be reused several times as a Fenton-like catalyst. Moreover, reduced $\mathrm{CuFe}_{2} \mathrm{O}_{4}$ displayed a superparamagnetic property, which allowed them to be easily separated and collected in practical applications.

\section{Conflicts of interest}

There are no conflicts to declare.

\section{Acknowledgements}

This work was supported by National Natural Science Foundation of China [51408119 and 41671468], The Science and Technology Project of Zhejiang Province (2017C33036) and Priority Academic Program Development of Jiangsu Higher Education Institutions (PAPD). The authors would like to thank Analytical Center of NIGLAS for making this study possible by making laboratory facilities available.

\section{References}

1 A. Ahmad, S. H. Mohd-Setapar, C. S. Chuong, A. Khatoon, W. A. Wani, R. Kumar and M. Rafatullah, RSC Adv., 2015, 5, 30801-30818.

2 J. L. Wang and L. J. Xu, Crit. Rev. Environ. Sci. Technol., 2012, 42, 251-325.

3 P. V. Nidheesh, R. Gandhimathi and S. T. Ramesh, Environ. Sci. Pollut. Res., 2013, 20, 2099-2132.

4 R. S. Ribeiro, A. M. T. Silva, J. L. Figueiredo, J. L. Faria and H. T. Gomes, Appl. Catal., B, 2016, 187, 428-460.

5 N. Panda, H. Sahoo and S. Mohapatra, J. Hazard. Mater., 2011, 185, 359-365.

6 L. J. Xu and J. L. Wang, Appl. Catal., B, 2012, 123, 117-126.

7 X. Y. Li, Y. Huang, C. Li, J. M. Shen and Y. Deng, Chem. Eng. J., 2015, 260, 28-36.

8 Y. Feng, C. Z. Liao and K. M. Shih, Chemosphere, 2016, 154, 573-582.
9 Y. B. Wang, H. Y. Zhao, M. F. Li, J. Q. Fan and G. H. Zhao, Appl. Catal., B, 2014, 147, 534-545.

10 D. H. K. Reddy and Y. S. Yun, Coord. Chem. Rev., 2016, 315, 90-111.

11 D. H. Bremner, A. E. Burgess, D. Houllemare and K. C. Namkung, Appl. Catal., B, 2006, 63, 15-19.

12 L. J. Xu and J. L. Wang, J. Hazard. Mater., 2011, 186, 256-264.

13 F. C. C. Moura, M. H. Araujo, R. C. C. Costa, J. D. Fabris, J. D. Ardisson, W. A. A. Macedo and R. M. Lago, Chemosphere, 2005, 60, 1118-1123.

14 R. Sharma, S. Bansal and S. Singhal, RSC Adv., 2015, 5, 60066018.

15 D. Wan, W. B. Li, G. H. Wang, L. L. Lu and X. B. Wei, Sci. Total Environ., 2017, 574, 1326-1334.

16 R. C. C. Costa, F. C. C. Moura, J. D. Ardisson, J. D. Fabris and R. M. Lago, Appl. Catal., B, 2008, 83, 131-139.

17 Y. B. Wang, H. Y. Zhao and G. H. Zhao, Appl. Catal., B, 2015, 164, 396-406.

18 J. Wang, C. Liu, J. S. Li, R. Luo, X. R. Hu, X. Y. Sun, J. Y. Shen, W. Q. Han and L. J. Wang, Appl. Catal., B, 2017, 207, 316-325. 19 F. Qi, W. Chu and B. B. Xu, Chem. Eng. J., 2015, 262, 552-562. 20 A. P. Grosvenor, B. A. Kobe, M. C. Biesinger and N. S. McIntyre, Surf. Interface Anal., 2004, 36, 1564-1574.

21 C. Reitz, C. Suchomski, J. Haetge, T. Leichtweiss, Z. Jaglicic, I. Djerdj and T. Brezesinski, Chem. Commun., 2012, 48, 44714473.

22 P. L. Wang, X. Zhou, Y. G. Zhang, L. P. Yang, K. K. Zhi, L. L. Wang, L. T. Zhang and X. F. Guo, RSC Adv., 2017, 7, 26983-26991.

23 M. C. Biesinger, L. W. M. Lau, A. R. Gerson and R. S. C. Smart, Appl. Surf. Sci., 2010, 257, 887-898.

24 M. Munoz, Z. M. de Pedro, J. A. Casas and J. J. Rodriguez, Appl. Catal., B, 2015, 176, 249-265.

25 K. Y. Li, Y. Q. Zhao, C. S. Song and X. W. Guo, Appl. Surf. Sci., 2017, 425, 526-534.

26 J. S. Zhang, T. J. Yao, C. C. Guan, N. X. Zhang, H. Zhang, X. Zhang and J. Wu, J. Colloid Interface Sci., 2017, 505, 130138.

27 S. T. Yang, W. Zhang, J. R. Xie, R. Liao, X. L. Zhang, B. W. Yu, R. H. Wu, X. Y. Liu, H. L. Li and Z. Guo, RSC Adv., 2015, 5, 5458-5463.

28 S. C. Hsieh and P. Y. Lin, J. Nanopart. Res., 2012, 14, 10.

29 Z. L. Shi, X. X. Wang and S. H. Yao, Chin. J. Inorg. Chem., 2015, 31, 696-702.

30 Q. Wang, S. L. Tian and P. Ning, Ind. Eng. Chem. Res., 2014, 53, 643-649.

31 T. Shahwan, S. Abu Sirriah, M. Nairat, E. Boyaci, A. E. Eroglu, T. B. Scott and K. R. Hallam, Chem. Eng. J., 2011, 172, 258266.

32 W. Z. Tang and R. Z. Chen, Chemosphere, 1996, 32, 947-958.

33 S. S. Lin and M. D. Gurol, Environ. Sci. Technol., 1998, 32, 1417-1423.

34 C. Lee, C. R. Keenan and D. L. Sedlak, Environ. Sci. Technol., 2008, 42, 4921-4926.

35 W. P. Kwan and B. M. Voelker, Environ. Sci. Technol., 2003, 37, 1150-1158. 